\title{
A Rare Case of Primary Breast Mucosa- Associated Lymphoid Tissue Lymphoma
}

\author{
Daliborka Marić1 ${ }^{,}$Dragan Stojanov², Saša Vujnovićc ${ }^{1}$, Violeta Kovačević Dragosavljević1 \\ ${ }^{1}$ University Clinical Centre of the Republic of Srpska, Banja Luka, Bosnia and Herzegovina \\ ${ }^{2}$ Clinic of Radiology, Clinical Centre Niš, Niš, Serbia
}

\section{SUMMARY}

Breast involvement by lymphoma is uncommon and poses challenges in diagnosis. Breast involvement by malignant lymphoma, whether primary or secondary, is a rare event. Primary breast lymphomas account for $0.38 \%-0.7 \%$ of all non-Hodgkin lymphomas, $1.7 \%-2.2 \%$ of all extranodal non-Hodgkin lymphomas, and only $0.04 \%-0.5 \%$ of all breast cancer cases. Most frequent primary breast lymphomas are diffuse large B cell lymphomas (53\%). Breast mucosa-associated lymphoid tissue (MALT) lymphomas account for a small fraction of all the MALT lymphomas $(1 \%-2 \%)$. Herein we report a case of a patient with primary breast MALT lymphoma and its presentation on different imaging modalities. Two years after the presentation and treatment with eight cycles of chemotherapy, the patient is alive and well, without evidence of residual disease or recurrence.

Key words: B-cell, mucosa-associated lymphoid tissue lymphoma, computed tomography, ultrasonography, mammary mammography 


\section{INTRODUCTION}

For radiologists but also clinicians breast involvement by lymphoma is unexpected, rare and challenging to diagnose. Radiological and morphological presentation of lymphoma in the breast can mimic both malignant and benign conditions and requires extra caution.

In the literature, seven hundred primary breast lymphomas (PBL) have been described as individual cases or a series of cases (1-3). Murat et al. (4) described that PBLs generally affect women, and only 10 cases have been reported in men. When breast lymphoma is diagnosed, it must be determined whether it originated in the breast or systemically. Nowadays, the definition devised by Wiseman and Liao (5) and modified by Hugh et al. is generally accepted in the literature to define PBLs (6):

- both mammary tissue and lymphomatous infiltrate present in close association in an adequate specimen;

- no evidence of widespread lymphoma by standard staging techniques or preceding extramammary lymphoma, although ipsilateral axillary node involvement is allowed if both lesions are present simultaneously. We report a rare case of a patient with primary breast mucosa-associated lymphoid tissue (MALT) lymphoma and its presentation on different imaging modalities. In our patient, only breast was involved.

\section{CASE REPORT}

A sixty-four-year-old woman presented with a two-month history of the right breast palpable painless lumps. She gave a history of the right breast lumps 17 years earlier, when biopsy revealed fibrocystic breast disease. Physical examination confirmed the presence of a firm mass on her right breast. There was no associated skin thickening or nipple retraction.

Conventional mammography demonstrated a radiopaque lesion with relatively unsharp contour in the outer right upper quadrant (RUQ) of the breast. No microcalcifications or spiculations were found. Ultrasound examination showed in RUQ hypoechoic nodules, measured $1.85 \times 1.85 \mathrm{~cm}$, with the central anechoic area (Figure 1).

Then the patient underwent extempore biopsy followed by lumpectomy. Pathological examination of the lumpectomy specimen and immunohistochemistry revealed that these cells were EMA-,
CK PAN-, NSE-, LCA+, CD3-, CD4-, CD5-, CD8-, CD 20+, CD79 ALFA+, bcl2+, CD43+, consistent with low grade MALT lymphoma.

A CT scan of the chest and abdomen (SOMATOM Sensation 16, Siemens; Erlangen, Germany) revealed right breast asymmetric tissue and nodules measuring $1.6 \mathrm{~cm}$ in the right axillary tail (Figure 2a and 2b). There was no evidence of splenomegaly or lymphadenopathy.

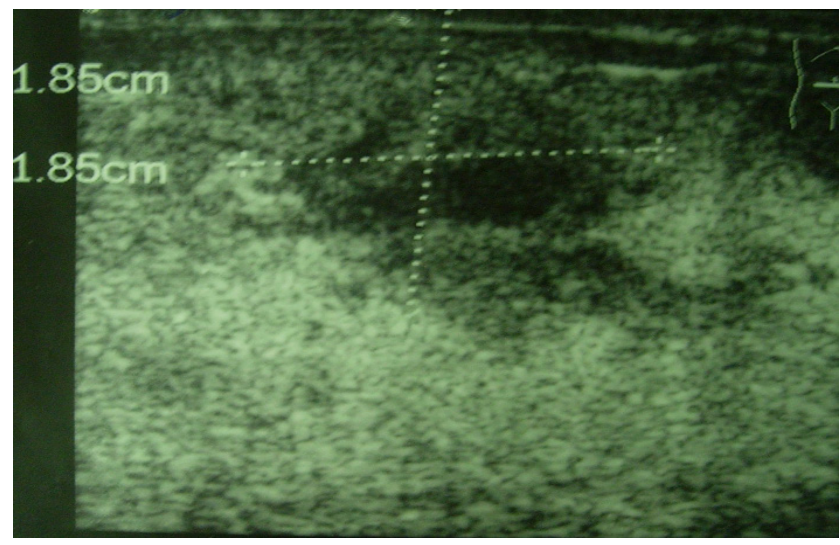

Figure 1. Right breast ultrasound demonstrating in RUQ hypoechoic nodules, measuring $1.85 \times 1.85 \mathrm{~cm}$ with the central anechoic area.

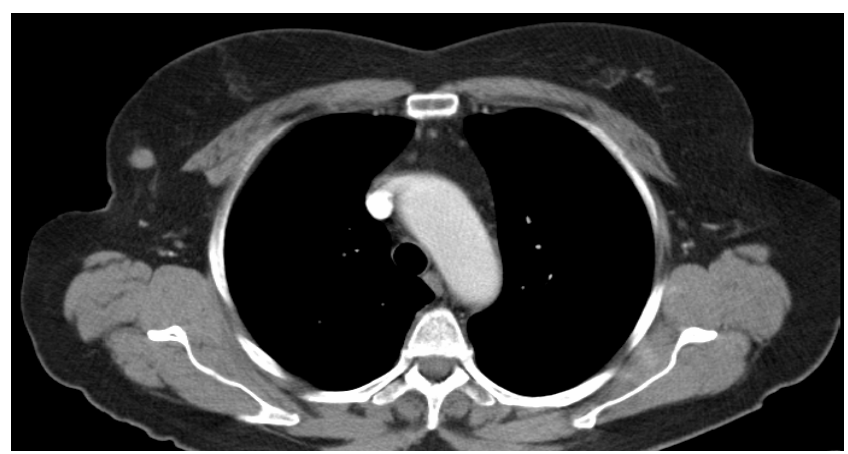

a

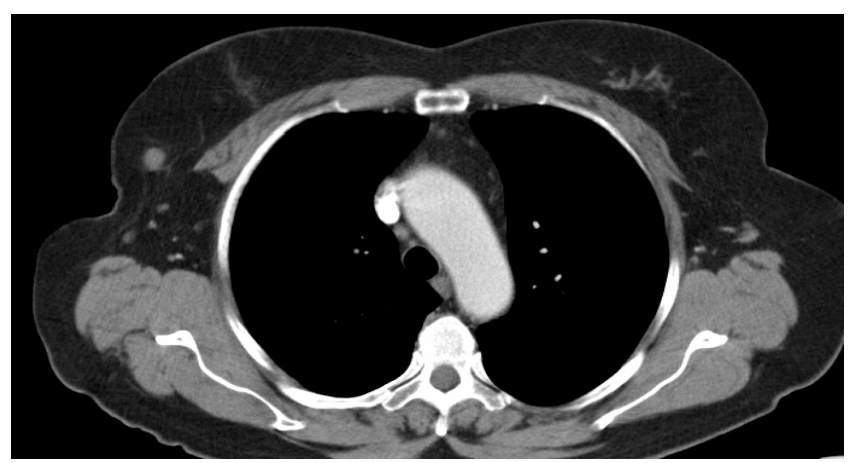

b

Figure $2 a$ and $2 b$. A CT scan of the chest revealing right breast asymmetric tissue and nodules measuring $1.6 \mathrm{~cm}$ in the right axillary tail with no evidence of lymphadenopathy. 


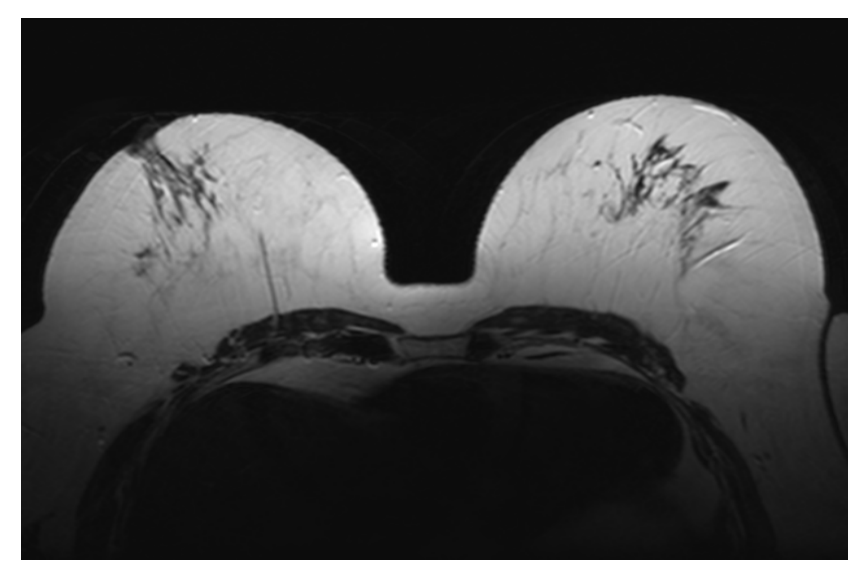

a

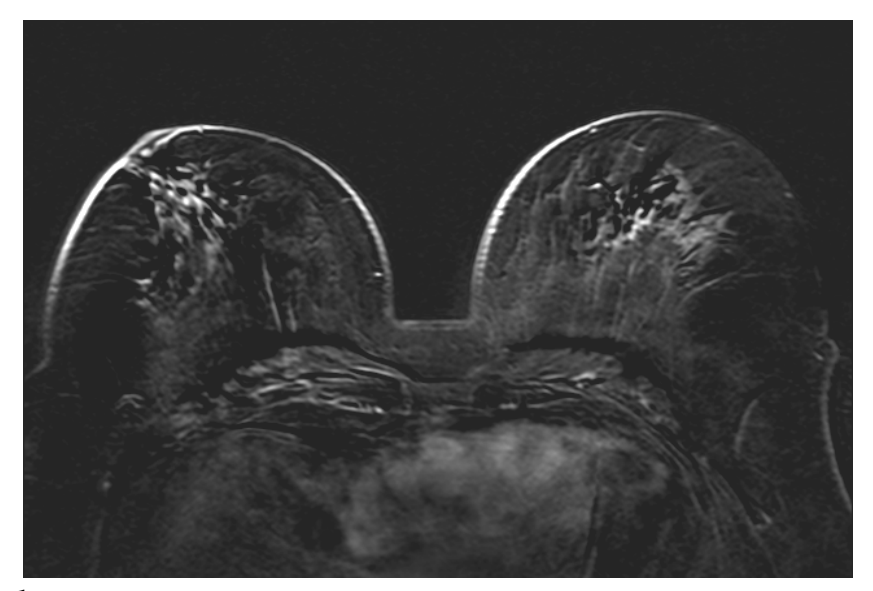

b

Figure $3 a$ and $3 b$. Axial T2-TSE and FL3D-DYN-SUB breast MRI demonstrating complete resolution and no evidence of residual disease or recurrence two years after presentation and therapy

Two years after presentation and treatment with eight cycles of chemotherapy, the patient underwent contrast-enhanced bilateral breast MRI (1.5T scenner MAGNETOM AVANTO, Siemens; Erlangen, Germany) which showed complete resolution and no evidence of residual disease or recurrence (Figure $3 a$ and $3 b$ ).

\section{DISCUSSION}

Mucosa-associated lymphoid tissue (MALT) lymphoma is extranodal lymphoma that originates from the mucosa that covers some organs and body cavities but not the lymph nodes. This is a low grade (indolent) lymphoma with histopathologic similarity to B-cell lymphomas of the marginal zone. In the gastrointestinal mucosa, MALT lymphomas were first described by Issacson and Wright in 1983 (7). The bronchial and the intestinal mucosa are the most frequent locations of MALT presentation. The salivary glands, conjunctiva, skin, thyroid and breast normally do not consist of organized lymphoid tissue, and MALT lymphoma might occur in those organs (8).

In 1987, Lamovec and Jancar first reported primary breast MALT lymphomas as a low-grade B-cell lymphoma (9). Primary breast lymphoma is rare. It only accounts for $0.38 \%-0.7 \%$ of all non-Hodgkin lymphomas (NHLs). Of all extranodal NHL, primary breast lymphoma appears in $1.7 \%-2.2 \%$, and only in $0.04 \%-$ $0.5 \%$ of all breast cancer cases (10-12). Of all the MALT lymphomas, breast MALT lymphomas appears in a small number of cases (1\%-2\%) (12).

Primary breast lymphomas can be presented on mammography in a several ways. In $25 \%$ it is reported as a unilateral diffuse involvement, in $8,3 \%$ as a bilateral diffuse involvement. Also, primary breast lymphomas can be presented as masses (solitary - 58\%; multiple unilateral masses $-8.3 \%$ ). The borders of masses have to be distinguished as irregular $(50 \%)$, partially defined $(37.5 \%)$, or well-defined borders (13/24). Our patient had solitary, unilateral mass with irregular borders.

In MRI, primary breast MALT lymphoma was described by Espinosa et al. (14) as isointense on T1weighted images, and hyperintense on T2-weighted images, nonspecific irregular enhancing foci on postcontrast images. During the wash-in phase of dynamic imaging, the lesions showed a rather fast initial enhancement (14).

We find in the reference literature that tumor size $(>4.5 \mathrm{~cm}$ ) and lymphomatous propagation to the lymph nodes of axilla are statistically significant negative prognostic factors (3). The patient that we reported had none of these factors. There is much difficulty in differentiating between breast carcinoma and primary breast lymphoma on the basis of preoperative imaging and biopsy specimens. For all primary breast lymphoma, the five-year survival rate is $70 \%$, and it was found that the relapse-free rate is $42 \%$ (15).

Our patient is alive more than two years after the presentation and therapy, with no recurrence. MALT lymphomas have good prognosis (11). CT scan, ultrasound examinations and chemo/radiotherapy are necessary for staging and treatment. On the other hand, surgery plays a role in obtaining the definitive diagnosis in this disease. 


\section{References}

1. Avenia N, Sanguinetti A, Cirocchi R, et al. Primary breast lymphomas: a multicentric experience. World J Surg Oncol 2010; 8:53-6. https://doi.org/10.1186/1477-7819-8-53

2. Jennings WC, Baker RS, Murray SS et al. Primary Breast Lymphoma. The Role of Mastectomy and the Importance of Lymph Node Status. Ann Surg 2007; 245:784-9.

https://doi.org/10.1097/01.sla.0000254418.90192.59

3. Uesato M, Miyazawa $Y$, Gunji $Y$, Ochiai T. Primary Non-Hodgkin's lymphoma of the breast: report of a case with special reference to 380 cases in Japanese literature. Breast Cancer 2005; 12:154-8.

https://doi.org/10.2325/jbcs.12.154

4. Murata T, Kuroda H, Nakahama T et al. Primary non-Hodgkin malignant lymphoma of the male breast. Jpn J Clin Oncol 1996; 26:243-7. https://doi.org/10.1093/oxfordjournals.jjco.a023222

5. Wiseman C, Liao KT. Primary lymphoma of the breast. Cancer 1972; 29:1705-12.

https://doi.org/10.1002/10970142(197206)29:6<1705::AID-

CNCR2820290640>3.0.CO;2-I

6. Hugh JC, Jackson FI, Hanson J, Poppema S. Primary breast lymphoma. An immunohistologic study of 20 new cases. Cancer 1990; 66:2602-11.

https://doi.org/10.1002/1097-

0142(19901215)66:12<2602::AID-

CNCR2820661224>3.0.CO;2-U

7. Isaacson PG, Wright DH. Malignant lymphoma of mucosa-associated lymphoid tissue. A distinctive type of B-cell lymphoma. Cancer 1983; 52:1410-6.

https://doi.org/10.1002/1097-

0142(19831015)52:8<1410::AID-

CNCR2820520813>3.0.CO;2-3

8. Gopal S, Awasthi S, Elghetany MT. Bilateral breast MALT lymphoma: a case report and review of the literature. Ann Hematol 2000; 79:86-9.

https://doi.org/10.1007/s002770050016

9. Lamovec J, Jancar J. Primary malignant lymphoma of the breast. Lymphoma of the mucosa-associated lymphoid tissue. Cancer 1987; 60:3033-41.

https://doi.org/10.1002/10970142(19871215)60:12<3033::AIDCNCR2820601230>3.0.CO;2-A

10. Mattia AR, Ferry JA, Harris NL. Breast lymphoma: a B-cell spectrum including lowgrade B-cell lymphoma of mucosa-associated lymphoid tissue. Am J Surg Pathol 1993; 17:57487.

https://doi.org/10.1097/00000478-199306000$\underline{00005}$

11. Brogi E, Harris NL. Lymphomas of the breast: pathology and clinical behavior. Semin Oncol 1999; 26:357-64.

12. Arber DA, Simpson JF, Weiss LM, Rappaport H. Non-Hodgkin's lymphoma involving the breast. Am J Surg Pathol 1994; 18:288-95. https://doi.org/10.1097/00000478-199403000$\underline{00009}$

13. Sabate JM, Gomez A, Torrubia S, et al. Lymphoma of the breast: clinical and radiologic features with pathologic correlation in 28 patients. Breast J 2002; 8:294-304 https://doi.org/10.1046/j.1524-4741.2002.08509.x

14. Espinosa AL, Daniel LB, Jeffrey SS et al. MRI of Mucosa-Associated Lymphoid Tissue Lymphoma. AJR 2005; 185:199-202. https://doi.org/10.2214/ajr.185.1.01850199

15. Wong WW, Schild SE, Halyard MY, Schomberg PJ. Primary non-Hodgkin lymphoma of the breast: the Mayo Clinic experience. J Surg Oncol 2002; 80:19-25. https://doi.org/10.1002/jso.10084 


\title{
Redak slučaj primarnog MALT limfoma dojke
}

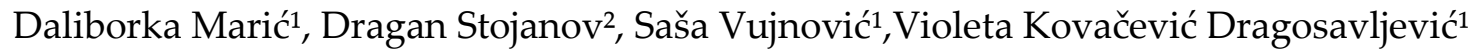 \\ ${ }_{1}^{1}$ Univerzitetski Klinički centar Republike Srpske, Banja Luka, Bosna i Hercegovina \\ ${ }^{2}$ Klinika za radiologiju, Klinički centar Niš, Niš, Serbia
}

\section{SAŽETAK}

Prisustvo limfoma u dojci je rijetko i predstavlja dijagnostički izazov. Maligni limfom u dojci, bilo primarni ili sekundarni, vrlo je rijedak slučaj. Primarni limfom dojke čini $0,38 \%-0,7 \%$ svih nehočkinskih limfoma; 1,7\%-2,2\% svih ekstranodalnih nehočkinskih limfoma; i samo 0,04\%-0,5\% svih karcinoma dojke. Najčešći primarni limfom dojke je difuzni limfom krupnih B-ćelija (53\%). MALT limfom dojke čini mali dio svih MALT limfoma (1\%-2\%). Predstavljamo slučaj bolesnice sa primarnim MALT limfomom dojke $\mathbf{i}$ njegovom prezentacijom na različitim radiološkim modalitetima. Dvije godine nakon otkrivanja $i$ sprovedenih osam ciklusa hemioterapije, bolesnica je još živa bez znakova recidiva bolesti.

Ključne reči: B-ćelije, MALT limfom, kompjuterizovana tomografija, ultrasonografija, mamografija dojke 
